\title{
Biological Age and Habitual Physical Activity in Relation to Physical Fitness in 12- and 13-Year-Old Schoolboys*
}

\author{
Han C. G. Kemper, Robbert Verschuur, Koos G. A. Ras, Jan Snel, Paul G. Splinter, \\ and Louis W. C. Tavecchio \\ Coronel Laboratory (Prof. Dr. R. L. Zielhuis) and Laboratory of Psychophysiology (Prof. Dr. \\ P. Visser), Jan Swammerdam Institute, University of Amsterdam
}

Received November 11, 1974

\begin{abstract}
Purpose: The purpose of this study was to investigate the relationship between biological age, habitual physical activity and anthropometrical and physiological characteristies in 12- and 13-year-old schoolboys $(n=70)$.
\end{abstract}

Methods: At the beginning and the end of the school year 1971/72 biological age was determined by measuring skeletal age from left hand X-ray photographs. Habitual physical activity was determined by questionnaire interview and pedometers.

Results: All anthropometrical characteristics showed significant correlations $(P<0.05)$ with skeletal age except for bicipital and tricipital skinfolds. Out of 9 physical fitness tests handgrip was the only test that showed a significant correlation (0.52) with skeletal age.

Pedometer scores gave significant negative correlations $(P<0.05)$ with anthropometrical characteristics except for tricipital skinfold. The fitness tests bent arm hang, 12 min run walk, sit and reach and $W_{170}$ showed significant correlations $(P<0.05)$ with pedometer scores.

Key words: Skeletal age - Habitual physical activity - Anthropometrical characteristics - Physical fitness characteristics.

\section{Introduction}

The effects of lessons in physical education on growth and development of children have been investigated extensively. The results of physical education programs are directly related to: 1 . qualitative and quantitative characteristics of the program itself, 2. characteristics of the subjects who participate in these programs.

The inconsistency in the results of studies concerning effectiveness of physical education can partly be explained by differences in content as well as frequency of the physical education programs as well as inadequate study designs (Wendler, 1936; Encausse, 1957; Groll, 1968; Schleusing et al., 1964; Tillman, 1965; Isaac et al., 1969; Cumming et al., 1969; La von Johnson, 1969; Saunders et al., 1969; Gabler, 1970; Buchberger, 1971; Rieckert et al., $1972 \mathrm{a}$, b; Rieckert and Gabler, 1972; Van der Hoeven, 1973; Kemper et al., 1973; Bar-Or and Zwiren, 1973;

* This study was supported in part by a grant from the Foundation for Education Research (SVO) and the Ministry of Health and Environmental Hygiene in The Hague (The Netherlands). Project number: 0185. 
Sprynarova, 1973). Besides that, most of these experiments deal with subjects who also differ in age and sex.

In our opinion there can be additional reasons for inconsistent results. As a substantial part of an investigation of the influence of a 5 versus a 3 lessons-a-week physical education program upon physical and mental development of 12- and 13-year-old boys at a secondary school (Kemper et al., 1974), we measured biological age and habitual physical activity. In a previous investigation (Kemper et al., 1973) we found that in subjects of same age and sex large differences exist in developmental stage and also in habitual physical activity.

The purpose of this study was to investigate the relationship between biological age, habitual physical activity and morphological and physiological characteristics.

\section{Material and Methods}

Subjects were 12- and 13-year-old boys from the first forms of a secondary school in Amsterdam (St. Ignatius College). From 82 boys 12 were excluded for medical and technical reasons.

At the beginning (pretest) and at the end (posttest) of the school year 1971/72 biological age was determined by measuring skeletal age from left hand X-ray photographs according to the method of Tanner et al. $(1959,1962)$. Ratings of 20 bones of hand and wrist are assigned by comparing the ossification stage of each bone with plates, diagrams and descriptions of the bone in question; of each bone 8 or 9 steps are distinguished in the development (Fig. 1).

With the aid of the Utilis 15/18 (Enraf, Delft) X-ray apparatus, photographs were taken of the hand with palm faced downward. The tube was centered at a distance of $80 \mathrm{~cm}$ above an Osray T-4 (Agfa-Gevaert) double wrapped film. Exposure time was $0.3 \mathrm{sec}$ with a tube voltage of $45 \mathrm{KV}$. In this way the local radiation was below $30 \mathrm{mR}$. All X-rays were rated by a previously trained examiner (Fig. 2).

Twice during the school year we determined out-of-school physical activity. Two methods were used: 1. estimation of time spent on physical activities by means of a questionnaire interview (Edholm, 1966), and 2. measurement of the scores on pedometers (Stunkard, 1960).

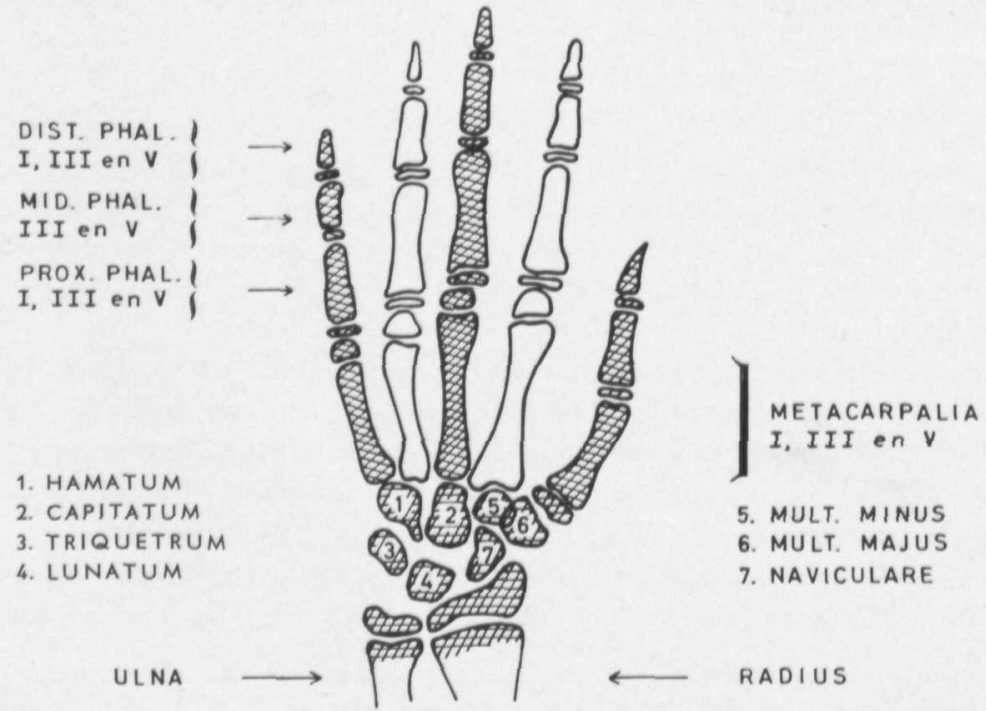

Fig. 1. Bones rated according to the Tanner-Whitehouse-Healy method $(1959,1962)$ 

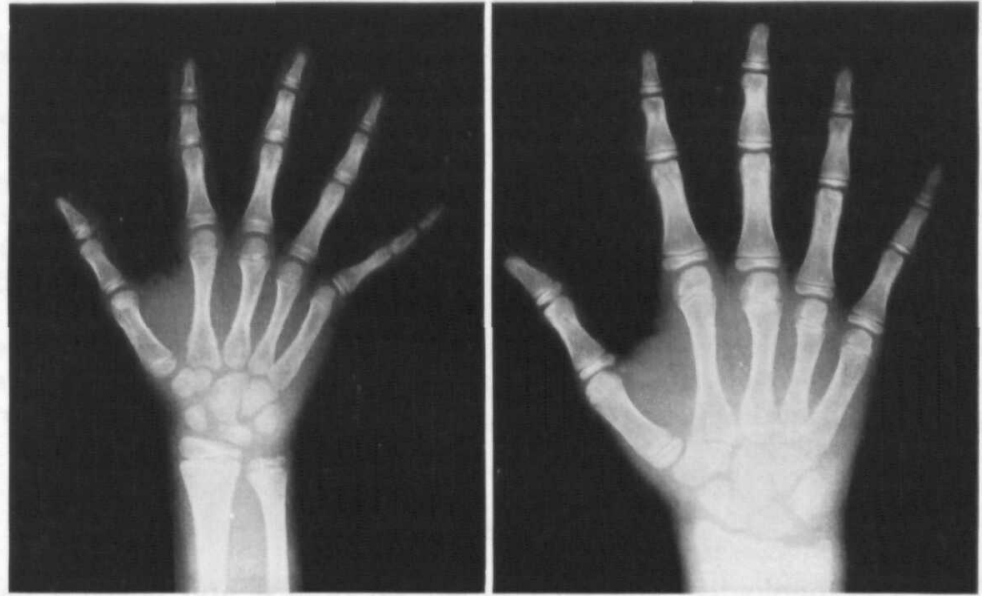

Fig. 2. Two left hand X-ray photographs from boys with same chronological age (12.4 years) but difference in skeletal age 10.9 (left) and 13.9 (right)

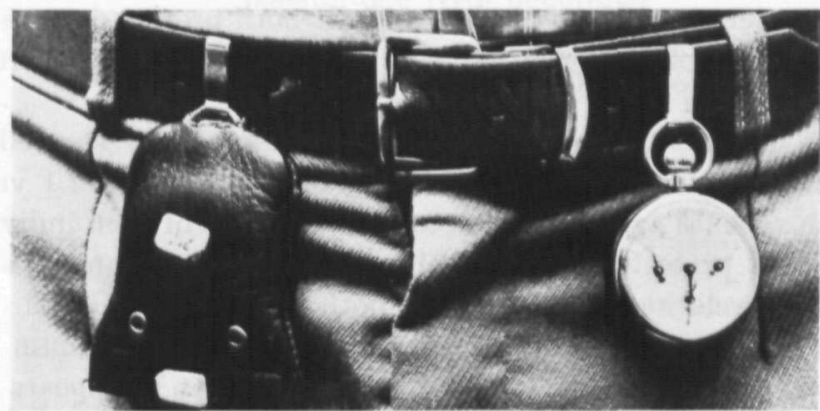

Fig. 3. Pedometer, attached to the waist of a subject (right), covered by a case (left)

To get more insight in the nature of the habitual physical activity, we also interviewed the boys by means of a questionnaire. The questionnaire concerned 3 main categories: transportation to and from school, participation in organised physical activity (sport clubs) and other physical activities during leisure time.

Pedometers (Post, Amsterdam) measured vertical displacements; attached to the waist, all movements of the centre of gravity are registered and totalised over a given period. This totalised score was used as a measure of the amount of physical activity. Assuming physical activity during school hours being quite comparable, we measured the leisure time activity systematically in 3 periods of the week: from Monday afternoon till Tuesday morning, from Wednesday noon till Thursday morning and from Friday afternoon till Monday morning (during the weekend). To avoid seasonal influences each measurement was done for each boy twice a year (during autumn and during spring) and only one measurement a week. To diminish influence of the instrument on behaviour of subjects, pedometers were covered by a case and seeled. They were told to be "universal clocks" which were supposed to measure body temperature, sweating rate and other physical aspects (Fig. 3).

The anthropometrical and physiological characteristics were measured at the beginning and the end of the school year; only pretest data are used. The anthropometrical characteristics, measured according to proposals of the International Biological Program (IBP) (Weiner et al., 1969) were: body weight, body height, width, circumference and skinfold measurements. 
The physiological characteristics measured were:

1. forced expiratory volume in 1 sec as a percentage of the vital capacity (FEV\%);

2. external load produced on a bicycle ergometer (Lode) at a heart rate of 170 beats per minute: physical working capacity $\left(\mathrm{W}_{170}\right)$. We chose the type of load used by the IBP in which the load was related to body weight. Each of the 4 constant loads lasted $3 \mathrm{~min}$. The first load was uniform for all subjects: 1 watt per kilogram body weight (Kemper, 1972); the increase in successive loads depended on the heart rate in the last minute of each load. The $W_{170}$ was calculated from the regression equation in which the load $(\mathrm{W} / \mathrm{kg})$ was the independent variable and the mean heart rate in the last $30 \mathrm{sec}$ of each work load was the dependent variable;

3. in addition we used a battery of 7 physical fitness tests including the following test items: Plate tapping (40 cycles time, in $0.1 \mathrm{sec})$, sit and reach $(\mathrm{cm}), 50 \mathrm{~m}$ shuttle run $(0.1 \mathrm{sec})$, bent arm hang (max. sec), vertical jump $(\mathrm{cm})$, handgrip with a Bettendorff dynamometer $(\mathrm{kg})$ and the 12-minute run walk $(\mathrm{m})$.

\section{Results}

In Table 1 chronological and skeletal age on pretest and posttest have been presented. On pretest the range in chronological age, averaging 12.5 years $( \pm 0.4)$, was 1.8 years; skeletal age, averaging 12.8 years $( \pm 0.8)$, had a range of 3.6 years. On posttest, i.e. 0.8 year after pretest, the same boys showed a range of 3.7 years in skeletal age, averaging 13.3 years $( \pm 0.8)$. In both pretest data as well as posttest data of chronological age the range of skeletal age was two times the range of chronological age.

Over the experimental period (0.8 year) skeletal age showed an average increase of 0.5 year, varying from child to child, from 0.0 to 2.1 years. Plotting this increase in skeletal age against pretest skeletal age of each individual (Fig. 4) as well as against pretest chronological age (Fig. 5) there appears to be no relationship; the correlation coefficients for both are $r=0.01$.

In Table 2 mean, standard deviation, minimum and maximum of individual pedometer scores are presented. From the mean scores it appears quite clearly that they become higher in relation with length of period of measuring. Remarkable inter-individual differences in habitual activity can be demonstrated in the observed minimum and maximum scores. In some periods these differences in

Table 1. Data of chronological and skeletal age of a group of 70 boys pupils from four parallel firsts forms of a secondary school St. Ignatius College in Amsterdam. In order to examine the increase in skeletal age during the terms 1971/72 the difference (diff.) of two moments of time (pretest, 8/71 and posttest, 5/72) were taken

Biological development distribution of boys age 12 and 13

\begin{tabular}{|c|c|c|c|c|c|c|}
\hline $\begin{array}{l}\text { Age } \\
\text { (dec. years) }\end{array}$ & time of test & $\bar{x}$ & s. d. & $\min$. & $\max$ & range \\
\hline \multirow{3}{*}{$\begin{array}{l}\text { Chronological } \\
\text { age }\end{array}$} & pretest & 12.5 & 0.4 & 11.9 & 13.7 & 1.8 \\
\hline & posttest & 13.2 & 0.4 & 12.6 & 14.4 & 1.8 \\
\hline & diff. & 0.7 & - & - & - & - \\
\hline \multirow[t]{3}{*}{ Skeletal age } & pretest & 12.8 & 0.8 & 11.0 & 14.6 & 3.6 \\
\hline & posttest & 13.3 & 0.8 & 11.7 & 15.4 & 3.7 \\
\hline & diff. & 0.5 & 0.5 & 0.0 & 2.1 & 2.1 \\
\hline
\end{tabular}




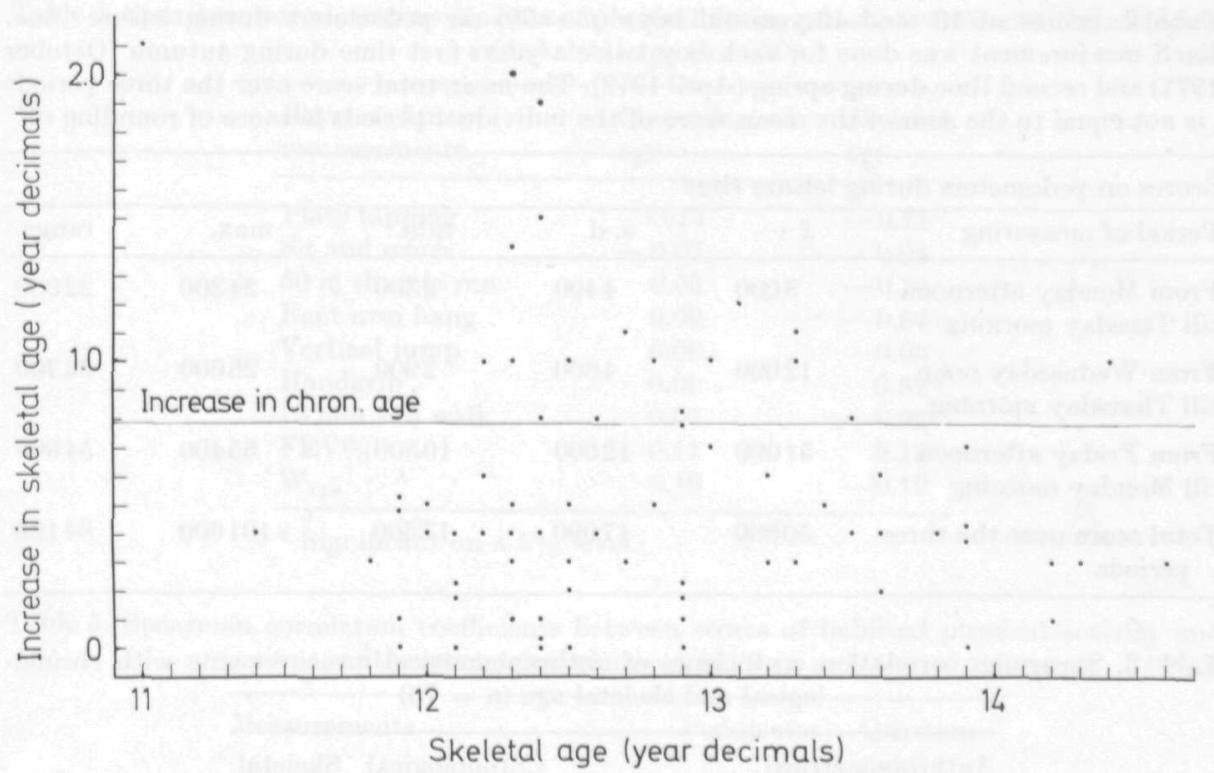

Fig. 4. Relationship between skeletal age on pretest (abcissa) and increase in skeletal age (ordinate) from pre- to posttest of the subjects

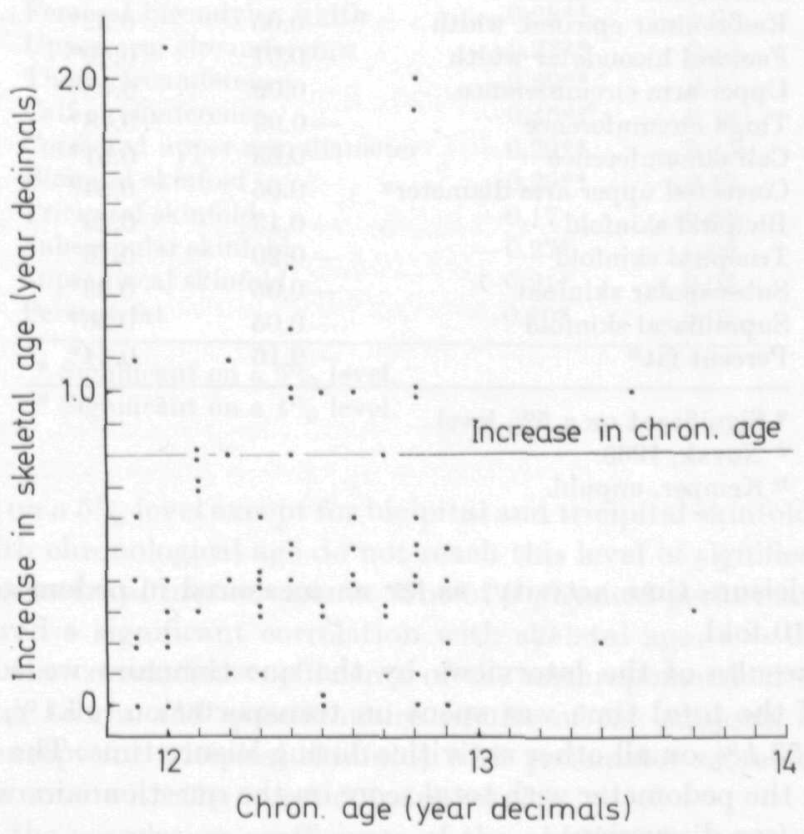

Fig. 5. Relationship between chronological age (abcissa) and increase in skeletal age (ordinate) from pre- to posttest of the subjects 
Table 2. Scores of 12- and 13-year-old boys $(n=70)$ on pedometers during leisure time. Each measurement was done for each boy twice a year: first time during autumn (October 1971) and second time during spring (April 1972). The mean total score over the three periods is not equal to the sum of the mean score of the individual periods because of rounding off

\begin{tabular}{lccccc}
\hline Scores on pedometers during leisure time & \multicolumn{3}{l}{} \\
\hline \begin{tabular}{l} 
Period of measuring \\
\hline $\begin{array}{l}\text { From Monday afternoon } \\
\text { till Tuesday morning }\end{array}$
\end{tabular} & 8000 & 4400 & 2300 & 24300 & 22000 \\
$\begin{array}{l}\text { From Wednesday noon } \\
\text { till Thursday morning }\end{array}$ & 12000 & 4600 & 2900 & 26600 & 23700 \\
$\begin{array}{l}\text { From Friday afternoon } \\
\text { till Monday morning }\end{array}$ & 31000 & 12600 & 10500 & 65400 & 54900 \\
$\begin{array}{l}\text { Total score over the three } \\
\text { periods }\end{array}$ & 50800 & 17000 & 17500 & 101600 & 84100 \\
\hline
\end{tabular}

Table 3. Spearman correlation coefficients of anthropometrical measurements with chronological and skeletal age $(n=70)$

\begin{tabular}{lrl}
\hline $\begin{array}{l}\text { Anthropometrical } \\
\text { measurements }\end{array}$ & $\begin{array}{l}\text { Chronological } \\
\text { age }\end{array}$ & $\begin{array}{l}\text { Skeletal } \\
\text { age }\end{array}$ \\
\hline Weight & -0.02 & $0.70^{*}$ \\
Height & 0.12 & $0.65^{*}$ \\
Biacromial diameter & 0.15 & $0.54^{*}$ \\
Biiliocristal diameter & -0.05 & $0.50^{*}$ \\
Radio-ulnar epicond. width & -0.07 & $0.52^{*}$ \\
Femoral bicondylar width & -0.09 & $0.49^{*}$ \\
Upper-arm circumference & -0.09 & $0.45^{*}$ \\
Thigh circumference & -0.03 & $0.48^{*}$ \\
Calf circumference & 0.05 & $0.51^{*}$ \\
Corrected upper-arm diametera & -0.13 & 0.20 \\
Bicipital skinfold & -0.20 & 0.16 \\
Tricipital skinfold & -0.05 & $0.33^{*}$ \\
Subscapular skinfold & -0.05 & $0.36^{*}$ \\
Suprailiacal skinfold & -0.16 & $0.24^{*}$ \\
Percent fatb & & \\
\hline
\end{tabular}

* Significant on a $5 \%$ level.

a Novak, 1963.

b Kemper, unpubl.

total habitual leisure time activity, as far as measured in pedometer scores, are 6-, 7 - or even 10 -fold.

From the results of the interviews by the questionnaire we could conclude that $30.8 \%$ of the total time was spent on transportation, $16.1 \%$ on organised activities and $53.1 \%$ on all other activities during leisure time. The correlation of total scores on the pedometer with total score on the questionnaire was significant $(0.50)$ but low (see discussion).

In Table 3 correlations have been listed between anthropometric characteristics and chronological and skeletal age. With skeletal age all correlation coefficients 
Table 4. Spearman correlation coefficients of physical fitness measurements with chronological and skeletal age $(n=70)$

\begin{tabular}{lcc}
\hline $\begin{array}{l}\text { Physical fitness } \\
\text { measurements }\end{array}$ & $\begin{array}{l}\text { Chronological } \\
\text { age }\end{array}$ & $\begin{array}{l}\text { Skeletal } \\
\text { age }\end{array}$ \\
\hline Plate tapping & -0.13 & -0.11 \\
Sit and reach & -0.07 & 0.04 \\
$50 \mathrm{~m}$ shuttle run & 0.03 & -0.10 \\
Bent arm hang & 0.00 & -0.04 \\
Vertical jump & 0.06 & -0.03 \\
Handgrip & 0.00 & $0.52^{*}$ \\
12 min run walk & 0.01 & -0.02 \\
FEV\% & -0.11 & 0.13 \\
$W_{170}$ & 0.19 & -0.12 \\
\hline
\end{tabular}

* Significant on a $5 \%$ level.

Table 5. Spearman correlation coefficients between scores of habitual physical activity and anthropometrical characteristics $(n=70)$

\begin{tabular}{lcc}
\hline Measurements & Pedometer & $\begin{array}{l}\text { Question- } \\
\text { naire }\end{array}$ \\
\hline Weight & $-0.40^{* *}$ & -0.05 \\
Height & $-0.42^{* *}$ & -0.02 \\
Biacromial diameter & $-0.35^{* *}$ & -0.06 \\
Biiliocristal diameter & $-0.26^{*}$ & -0.05 \\
Radio-ulnar epicond. width & $-0.24^{*}$ & +0.05 \\
Femoral bicondylar width & $-0.28^{* *}$ & +0.04 \\
Upper-arm circumference & $-0.32^{* *}$ & -0.13 \\
Thigh circumference & $-0.29^{* *}$ & -0.10 \\
Calf circumference & $-0.40^{* *}$ & -0.14 \\
Corrected upper-arm diameter & $-0.29^{* *}$ & -0.13 \\
Bicipital skinfold & $-0.29^{* *}$ & -0.17 \\
Tricipital skinfold & -0.17 & -0.08 \\
Subscapular skinfold & $-0.27^{*}$ & -0.09 \\
Suprailiacal skinfold & $-0.21^{*}$ & +0.05 \\
Percent fat & $-0.20^{*}$ & -0.07 \\
\hline
\end{tabular}

* Significant on a $5 \%$ level.

** Significant on a $1 \%$ level.

are significant on a $5 \%$ level except for bicipital and tricipital skinfolds. Correlation coefficients with chronological age do not reach this level of significance with any of the anthropometrical measurements. Out of 9 physical performance tests only handgrip showed a significant correlation with skeletal age: $r=0.52$ (Table 4).

In Table 5 the correlation coefficients of the anthropometrical characteristies with pedometer scores and questionnaire results of the subjects are listed. All correlations (except for tricipital skinfold) with pedometer scores are significant $(P<0.05)$ but none with the questionnaire results.

In Table 6 the correlation coefficients of the physical fitness tests with pedometer scores and questionnaire results are given. Out of 9 tests the bent arm hang $(0.34), 12$ min run walk $(0.31)$, sit and reach $(0.27)$ and $W_{170}(0.21)$ are sig- 
Table 6. Spearman correlation coefficients between scores of habitual physical activity and physical fitness characteristics $(n=70)$

\begin{tabular}{lll}
\hline Measurements & Pedometer & $\begin{array}{l}\text { Question- } \\
\text { naire }\end{array}$ \\
\hline Plate tapping & -0.13 & -0.08 \\
Sit and reach & $+0.27^{*}$ & +0.10 \\
$50 \mathrm{~m}$ shuttle run & -0.08 & -0.12 \\
Bent arm hang & $+0.34^{* *}$ & $+0.23^{*}$ \\
Vertical jump & +0.07 & +0.02 \\
Handgrip & -0.11 & +0.08 \\
12 min run walk & $+0.31^{* *}$ & $+0.30^{* *}$ \\
$W_{170}$ & $+0.21^{*}$ & $+0.35^{* *}$ \\
FEV\% & -0.11 & -0.17 \\
\hline
\end{tabular}

* Significant on a $5 \%$ level.

** Significant on a $1 \%$ level.

nificantly correlated $(P<0.05)$ with pedometer scores. Only the $W_{170}(0.35)$, 12 min run walk $(0.30)$ and bent arm hang had significant $(P<0.05)$ correlations with the questionnaire.

\section{Discussion and Conelusions}

Subjects were within a small range of chronological age. It is well known that in boys within the chronological age period of 12 to 13 years maturation can start in combination with growth spurt. Clarke (1971) and Bouchard et al. (1968) reported the greatest range in skeletal age ( 7.1 and 5.7 respectively) in boys at chronological age of 13 years. The range in skeletal age of our subjects, however, was 3.6 (pretest) and 3.7 (posttest) years. A possible explanation for this much smaller range may be sought in the different ways of selection of these populations: In the present study subjects had a level of intelligence which was superior to that of the mean of their age group and also a probably smaller variation in socioeconomic status than in the studies of Clarke (1971) and Bouchard et al. (1968).

We also measured total activity during normal lessons of physical education. The score of each lesson was obtained by averaging scores of 5 randomly chosen pupils. Depending on the teacher the mean score for 10 lessons of physical education varied from 2670 to 3250 (Table 7). Assuming a predicted score of 6000 as result of two extra lessons a week, this increase in physical activity means for a very inactive boy, with a pedometer score of 24000 a week, an increase of his total activity of $25 \%$. However, for a physically very active class-mate with a score of 180000 a week, the same two extra lessons result in an increase of total habitual activity of only $3 \%$. It is obvious that for both subjects the same training effect cannot be expected.

The results of the questionnaire did reveal that $30.8 \%$ of leisure time activity was spent on transportation to and from school; nearly all boys went to school by bicycle. Because the pedometers were not able to register this kind of activity, the data of the questionnaire gave us supplementary information about the habitual physical activity of the boys. It also explains the relatively low correlation $(0.50)$ between both instruments. 
Table 7. Mean scores on pedometers during 10 lessons in physical education. The same set of lessons was given by 4 different teachers (A-D). The score of each lesson for each class was obtained by averaging the scores of 5 randomly chosen pupils

\begin{tabular}{lrrrr}
\hline & \multicolumn{3}{l}{ Teacher } & \\
\cline { 2 - 5 } & \multicolumn{1}{c}{$\mathrm{A}$} & \multicolumn{1}{c}{$\mathrm{B}$} & \multicolumn{1}{c}{$\mathrm{C}$} & \multicolumn{1}{c}{$\mathrm{D}$} \\
\hline Mean $(\bar{x})$ & 2880 & 3250 & 2670 & 3080 \\
Stand. dev. (s.d.) & 790 & 570 & 870 & 920 \\
Minimum & 1960 & 2390 & 1730 & 2150 \\
Maximum & 4240 & 4050 & 3940 & 4460 \\
Range & 2180 & 1660 & 2210 & 2310 \\
\hline
\end{tabular}

The statistical significant correlations of pedometer scores with anthropometrical characteristics are negative. Boys with a high pedometer score (high physically activity) appear to have a relatively low body weight and height, small diameters, circumferences and skinfolds. In other words the most physically active pupils are small, narrow and lean, they show the somatotype of the endurance athlete (Tanner, 1964).

The significant correlations of the $\mathrm{W}_{170}$ and the 12 min run walk with pedometer scores as well as with questionnaire results - tests which are assumed to be a measure of aerobic power (cardiovascular endurance) - do suggest a relationship between habitual physical activity and physical fitness similar to habitual physical activity and body build, body composition.

The relationship of anthropometrical and physiological characteristics with skeletal and chronological age is another point that we have to discuss. Bouchard et al. (1968), Beunen et al. (1972) and Borms (1972) investigated the relationship between anthropometrical characteristics and chronological and skeletal age. Bouchard et al. (1968) could prove in 8-18-year-old subjects small, but consistently somewhat higher correlation coefficients between anthropometrical characteristics and skeletal age than with chronological age. In our study and that of Beunen et al. (1972) and Borms (1972) with 12-year-old boys anthropometrical characteristics show significant correlation coefficients with skeletal age, but at the same time the correlations with chronological age were low and not significant. This discrepancy could possibly be explained by differences in age range of the populations studied. In a group with small differences in age, as was the fact in our study and that of Beunen et al. (1972) and Borms (1972), chronological age is of no value as predictor of anthropometrical characteristics of this population consisting of low and early maturing individuals. In populations with much larger age range (Bouchard et al., 1968) anthropometrical characteristics of 10-year-old boys are always smaller than of 16-year-old boys whether they are late or early maturing.

The generally low correlations with physiological characteristics can be accounted for by motivational factors inevitably connected with this kind of measurements and with the fact that the subjects involved in this experiment were not volunteers but assigned from the first forms of a secondary school.

The only significant correlation with skeletal age was handgrip (0.52). This result is also in close agreement with those of Borms (1972), who found a correla- 
tion coefficient of 0.45 . Aside from physical factors, motivation could account for this consistent correlation. In performing the physical fitness test it was our experience that the boys were always highly motivated in performing the handgrip, more than in any other test.

Acknowledgements. The authors wish to express their appreciation to Jos Put, Ed Schut and Loek Toepoel, teachers in physical education on the St. Ignatius College and to our subjects who so willingly gave up their time and comfort to participate in these experiments.

We also acknowledge the assistance of J. J. L. Pieters (CIVO, TNO) in taking the photographs and of Mrs. C. Ijkel-van Anraad in rating the X-rays.

\section{References}

Bar-Or, Zwiren, L. D.: Physiological effects of increased frequency of physical education classes and of endurance conditioning on 9-10 year old girls and boys. In: Proc. 4th Int. Symp. Pediatric Work Physiology, Natanya, 183 (1973)

Beunen, G., Ostyn, M., Renson, R., Simons, J., Swalus, P., Gerven, D. van, Willems, E. J.: Skeletleeftijd en fysische ontwikkeling bij twaalfjarige jongens. Arch. belges Méd. soc. $\mathbf{2}$, $102(1972)$

Borms, J.: Een transversale studie over de relaties tussen skeletale leeftijd, lichaamsbouw, somatotype, lichaamsrijping en lichamelijke prestatie geschiktheid bij 12 jarige jongens van het lager onderwijs. Diss. V. U., Brussel 1972

Bouchard, C., Hollmann, W., Herkenrath, G.: Relations entre le niveau de maturité biologique, la participation à l'activité physique et certaines structures morphologiques et organiques chez des garçons de huit à dix-huit ans. Biométrie Humaine 3, 101 (1968)

Buchberger, J.: Der Einfluß verschiedener Trainingsarten auf die Arbeitskapazität von Jugendlichen. Wien. med. Wschr. 121, 51/52, 938 (1971)

Clarke, H. H.: Physical and motor tests in the Medford boys' growth study. New York: Prentice Hall 1971

Cumming, G. R., Goulding, D., Baggley, G.: Failure of school physical education to improve cardiorespiratory fitness. Canad. med. Ass. J. 101, 2, 69 (1969)

Edholm, O. G.: The assessment of habitual activity. In: Physical Activity in Health and Disease. Proc. of Beitostölen Symp., Universitetsforlaget, 1966

Encausse, P.: Influence des activités physiques et sportives sur le développement intellectuel et physique en milieu scolaire. Paris: Imprimerie Nationale 1957

Gabler, H.: Zur Einführung einer Sportzugklasse. Die Leibeserziehung 1, 4 - 6 (1970)

Groll, H.: Neuere Schulversuche zur täglichen Turnstunde in Frankreich, in der Schweiz und in Österreich. In: Idee und Gestalt, III, 137-152. Wenen: Öst. Bundes Verlag 1968

Hoeven, H. C. van der: Lichamelijke oefening en bewegingsvaardigheid. Scriptie. Univ. van Nijmegen, 1973

Isaac, J., Wilmart, C., Van den Bossche, F., Marneffe, O., Colemont, A., Ide, H., Van Kerckhove, E.: Het pedagogisch half-time stelsel van Cuesmes. Sport 2, 84 (1969)

Johnson, C. La von: Effects of 5-day-a-week versus 2- and 3-day-a-week physical education class on fitness, skill, adipose tissue and growth. Res. Quart. 40, 1, 93 (1969)

Kemper, H. C. G.: Heart rate during bicycle ergometer exercise in watts per kilogram body weight of 12 and 13 year old boys. Z. Kinderheilk. 113, 161 (1972)

Kemper, H. C. G.: The influence of extra lessons in physical education on physical and mental development of 12 and 13 year old boys. Physical Fitness, 212 - 216. Prague: Universita Karlova 1973

Kemper, H. C. G., Ras, K., Snel, J., Splinter, P., Tavecchio, L. W. C., Verschuur, R.: The influence of extra lessons in physical education upon physical and mental development of 12 and 13 year old boys at a secondary school. Haarlem: De Vrieseborch 1974

Rieckert, H., Gabler, H.: Der Trainingseffekt einer täglichen Sportstunde auf das körperliche Leistungsvermögen von 11-12jährigen Schülern. Sportarzt und Sportmed. 2, 21 (1972)

Rieckert, H., Gabler, H., Brandner, F.: Vergleichende Untersuchungen im Schul- und Leistungssport. Ärztl. Forsch. 36, 32-36 (1972 b) 
Rieckert, H., Gabler, H., Hinneberg, G., Schnezer, W.: Drei Jahre tägliche Sportstunde in einer Mädchenklasse. Med. Welt 23, 1115-1117 (1972a)

Saunders, R. J., Montoye, H. J., Cunningham, D. A., Kozar, A. J.: Physical fitness of high school students and participation in physical education classes. Res. Quart. 40, 3, 552 (1969)

Schleusing, G., Rieger, H.: Längsschnittuntersuchung über die Wirkung des sportlichen Trainings auf den kindlichen Organismus vom 11. bis 14. Lebensjahr. Z. Alternsforsch. 17, 3,258 (1964)

Sprynarova, S.: The impact of motor activity level on physical fitness during adolescence. Physical Fitness, $371-374$. Prague: Universita Karlova 1973

Stunkard, A.: A method of studying physical activity in man. Amer. J. clin. Nutr. 8, 595 $(1960)$

Tanner, J. M.: The physique of the Olympique athlete. London: Allen and Unwin 1964

Tanner, J. M., Whitehouse, R. H., Healy, M. J. R.: Part I: Standards for skeletal age (1959); Part II: A new system for estimating skeletal maturaty from the hand and wrist, with standard derived from a study of 2600 healthy British children. Paris, Int. Children's Center 1962

Tillman, K.: Relationship between physical fitness and selected personality traits. Res. Quart. 36, 483 (1965)

Weiner, J. S., Lourie, J. A.: IBP-Handbook, No. 9: Human biology, a guide to field methods. Oxford: Blackwel] 1969

Wendler, F.: Ǔber die Einwirkungen täglichen Turnens auf die Kinder. Diss., Univ. Hamburg 1936

Dr. H. C. G. Kemper

Jan Swammerdam Institute

1e Const. Huygensstraat 20

Amsterdam, The Netherlands 